\title{
XLVII. Additional remarks on the law of magnetic attractions and repulsions
}

\author{
Rev. William Ritchie LL.D. F.R.S.
}

To cite this article: Rev. William Ritchie LL.D. F.R.S. (1836) XLVII. Additional remarks on the law of magnetic attractions and repulsions, Philosophical Magazine Series 3, 8:46, 242-243, DOI: $10.1080 / 14786443608648856$

To link to this article: http://dx.doi.org/10.1080/14786443608648856

册 Published online: 01 Jun 2009.

Submit your article to this journal $₫$

Џ Article views: 2

Q View related articles $₫$ 
diaphragm $d$ into $c$, and passes out through the pipes $p p$; this is now lighted, and it burns with a red unsteady flame; then the oxygen stopcock is turned gradually, when this gas passes through the holes into $c$, where it mixes with the hydrogen, and they come out in perfect union at the pipes $p, p$. The hydrogen cock is now fully opened, and the other cock gradually opened and adjusted till the lime-ball gives out its most brilliant light, when the hydrogen flame entirely disappears.

The difficulties we encountered and the extraordinary shifts we were put to would be very amusing to you, but they are too long for a letter; suffice it to say, that in the end the experiment succeeded beyond our most sanguine expectation. The Pasha was delighted with its performance, and has taken the apparatus to his palace. I have since exhibited to him coal-gas light, which I managed much easier, and have drawn out my estimates for this light and oil; but no doubt the latter will be preferred, and I soon expect to be at work in putting in proper repair the lighthouses of Fanaraki. I am anxiously waiting your further description of Beale's light, which I will also show to the Pasha, who takes great interest in all these matters.

W. H. BarLow.

XLVII. Additional Remarks on the Laro of Magnetic Attractions and Repulsions. By the Rev. William Ritchie, LL.D. F.R.S.*

A $S$ Mr. Fox still seems to think that the law of magnetic $A$ attractions is inversely as the distance between the ends of the attracting magnets, without any reference rehatever to their form, the following considerations will, I think, convince him and every impartial inquirer that the supposed law has no existence in nature.

Let two magnets be formed, of plate steel, into the annexed figure, having the poles at $\mathrm{P}, \mathrm{P}^{\prime}$, and consequently further from the ends $a, b$ than if the bar were rectangular; then the attraction between those magnets will follow very different law from that which exists when

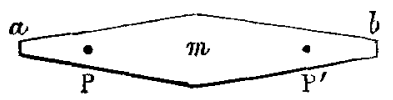
the bars are equally broad. The fact is, the supposed law obtained by measuring from the ends of the magnet will change with the length of the magnets, their form, and even with the uniformity of the temper.

* Communicated by the Author. 


\section{Mr. Woolhouse on the Theory of Gradients on Raitways. 243}

The law in question, then, being a function of so many variable quantities, must be one of extreme complexity, perhaps beyond the powers of the most refined analysis to unfold.

XLVIII. On the Theory of Gradients on Railways. By Mr. W. S. B. Woolhouse.

To the Editors of the Philosophical Magazine and Journal.

\section{Gentremen,}

A S Dr. Lardner and Mr. Barlow, in your Numbers for A January and February, hold out conflicting opinions on the theory of gradients on railways, and have left the subject in a state more calculated to create doubts in the minds of the less informed of your readers than to lead them towards the formation of settled conclusions, perhaps you will favour me with the insertion of a few words, by way of explanation, as far as the philosophy of the question presents itself to my mind. Mr. Barlow, without absolutely saying which of the two solutions is wrong, though probably quite conclusive in his own view of the matter, first states his objection to the arithmetical results of the formula employed by Dr. Lardner for the velocity, in certain cases, then gives an outline of his principle of investigation, and finally expresses himself "quite content to leave the decision to those whose minds have not already received a bias from preconceived notions of the forces." Whatever sentiments may prevail as to the competency of my opinions on such a subject, it will at least be acknowledged that I possess the qualification of being free from the bias here alluded to, and I am induced to hope that your readers will, on this very ground, acquit me of any imaginable interference in thus undertaking, voluntarily, the examination of a point that has already had the attention of such distinguished individuals. By close and continued application of particular opinions to particular subjects, it is indeed surprising how they fix themselves in the mind, and become ultimately, whether true or false, of almost a fundamental character. But Ido not consider this observation to be applicable to the present case. It is my wish to simplify and expose the truth as far as I can perceive it. I do not, however, intrude the present remarks in elucidation of the subject without some degree of hesitation, although quite free from apprehension as to their theoretical soundness. To many of your readers, who must be far from satisfied with the present situation of the question, I nevertheless feel myself justified in submitting them. 